\title{
Sodium Silicate Reduces Postharvest Decay on Hami Melons: Induced Resistance and Fungistatic Effects
}

Y. Bi, Key Laboratory of Photosynthesis and Environmental Molecular Physiology, Institute of Botany, Chinese Academy of Sciences, and Department of Food Science, Gansu Agricultural University; S. P. Tian, Key Laboratory of Photosynthesis and Environmental Molecular Physiology, Institute of Botany, Chinese Academy of Sciences; Y. R. Guo and Y. H. Ge, Department of Food Science, Gansu Agricultural University; and G. Z. Qin, Key Laboratory of Photosynthesis and Environmental Molecular Physiology, Institute of Botany, Chinese Academy of Sciences

\begin{abstract}
Bi, Y., Tian, S. P., Guo, Y. R., Ge, Y. H., and Qin, G. Z. 2006. Sodium silicate reduces postharvest decay on Hami melons: Induced resistance and fungistatic effects. Plant Dis. 90:279-283.

The effect of sodium silicate ( $\mathrm{Si}$ ) for control of decay was tested in Hami melons (Cucumis melo L. var. inodorus Jacq.). Si significantly inhibited mycelial growth of Alternaria alternata, Fusarium semitectum, and Trichothecium roseum in vitro. Si at $100 \mathrm{mM}$ was more effective than $\mathrm{Si}$ at 25 or $50 \mathrm{mM}$ at controlling the diseases caused by the three pathogens, whereas Si at $200 \mathrm{mM}$ was phytotoxic. Si treatments applied at $100 \mathrm{mM}$ pre-inoculation with T. roseum had lower decay incidence and severity than treatments applied post-inoculation. The protection of Si was correlated with the activation of two families of defense-related enzymes, peroxidase and chitinase. Accumulation of both enzymes was induced in fruit treated with $\mathrm{Si}$ and challenged by $T$. roseum $24 \mathrm{~h}$ later, and was sustained for at least 9 days in 'New Queen' and 10 days in '8601' at room temperature. It appeared that induced resistance was an important mechanism of disease control in Hami melons treated with Si.
\end{abstract}

Alternaria, Fusarium, and pink rots caused by Alternaria alternata, Fusarium spp., and Trichothecium roseum, respectively, account for most of the postharvest losses of Hami melons (5). These pathogens are controlled primarily by chemical fungicides $(1,22)$. However, due to potential problems related to public health associated with pesticide use, development of fungicide resistance by pathogens, and potential harmful effects on the environment, as well as the desire to reduce losses while also reducing the use of fungicides, new strategies for control have been proposed (16).

Silicon is the second most abundant atom in the Earth's crust (37). Biologically, it is a common but generally minor element in the majority of living organisms, occurring as amorphous silica $\left(\mathrm{SiO}_{2} \mathrm{nH}_{2} \mathrm{O}\right)$ and soluble silicic acid $\left(\mathrm{Si}(\mathrm{OH})_{4}\right)$ (29). There are several hypotheses concerning the role of silicon in plants, including a positive effect on reproduction, alleviation of metal toxicity and nutrient imbalance, provision of structural rigidity, and increased resistance to fungal diseases such as powdery mildews and root rots $(4,17)$. Soluble silicon has shown potential for the

Corresponding author: S. P. Tian

E-mail: tsp@ibcas.ac.cn

Accepted for publication 23 September 2005.

DOI: 10.1094/PD-90-0279

(C) 2006 The American Phytopathological Society control of fungal diseases in cherry fruit (27), cucumber (14), muskmelon and zucchini squash (24), peach fruit (8), and pear fruit $(32,33)$. The mechanisms responsible for the protection of plants from fungal diseases by silicon are not well understood. Silicon may act by eliciting biochemical defense reactions, including the accumulation of lignin, phenolic compounds, and pathogenesis-related proteins in the infected plants $(14,18)$.

The objectives of this study were to (i) examine the utility of applying sodium silicate $(\mathrm{Si})$ as an alternative postharvest treatment to conventional fungicides for managing decay in Hami melons, (ii) determine the effects of $\mathrm{Si}$ on disease development after either artificial or natural infection with the three major postharvest pathogens, and (iii) investigate whether induced resistance is involved in suppression of fungal decay in melon by $\mathrm{Si}$.

\section{MATERIALS AND METHODS}

Plant material. Hami melons (Cucumis melo L. var. inodorus Jacq.) cvs. New Queen and 8601 were obtained from Huangdun State Farm, Dunhuang, Gansu. The fruit were exposed to natural infection while growing in the field. The major field disease was Phytophthora rot (caused by a Phytophthora sp.) at this farm. Latent infections in growing fruit involved Alternaria rot (caused by $A$. alternata) and Fusarium rot (caused by a Fusarium sp.). The fruit were harvested at the beginning of physiological maturity (42 to 43 days after full bloom for New Queen and 55 to
56 days after full bloom for 8601), sorted for uniform size and absence of obvious injuries, packed individually in 35-cm-long net bags of foam plastic, and put in the standard melon-shipping boxes (four melons/box). Fruit were transported to the laboratory and stored at room temperature $\left(22 \pm 2^{\circ} \mathrm{C}\right)$ with relative humidity $(\mathrm{RH})$ of 55 to $60 \%$.

Source of pathogens and inoculum production. A. alternata (Fr.:Fr.) Keissl., Fusarium semitectum Berk. et Ravenel, and Trichothecium roseum (Pers.:Fr.) Link were isolated from Hami melons with fruit decay and maintained on potato dextrose agar (PDA) at $4^{\circ} \mathrm{C}$. Conidia of the pathogens were obtained from 10-day-old PDA cultures incubated at $25^{\circ} \mathrm{C}$. To obtain conidia, the cultures were flooded with sterile water containing $0.05 \%$ Tween 20 and rubbed gently with a glass rod. Mycelium was removed from the suspensions by filtering through two layers of cheesecloth. The spore count was determined with a hemacytometer, and the concentration was adjusted to $1 \times 10^{5}$ spores $\mathrm{ml}^{-1}$ with distilled water.

Preparation of $\mathrm{Si}$ and postharvest treatment. Si (Aldrich, sodium silicate solution, $27 \% \mathrm{SiO}_{2}$ ) was prepared as 25 , 50,100 , and $200 \mathrm{mM}$ solutions with distilled water. Asymptomatic fruit were dipped for $10 \mathrm{~min}$ in the various concentrations of Si and air dried. Control fruit were dipped in distilled water. The treated fruit were repacked individually in 35 -cm-long net bags of foam plastic, put in standard melon-shipping boxes (four melons/box), and stored at room temperature $\left(22 \pm 2^{\circ} \mathrm{C}\right.$, RH 55 to $60 \%$ ) until subjected to artificial inoculation or natural infection.

In vitro assays. The effect of $\mathrm{Si}$ on mycelial growth of the pathogens was assayed using the method of Aharoni et al. (2). Si treatments at $0,12.5,25,50$, and $100 \mathrm{mM}$ were tested against $A$. alternata, $F$. semitectum, and $T$. roseum. The substances were added into PDA after the PDA was autoclaved for $15 \mathrm{~min}$ and cooled to 65 to $70^{\circ} \mathrm{C}$. A 5-mm-diameter disc of mycelial mat from a 7-day-old culture was placed in the center of each petri plate. Colony diameter of the fungi was measured daily for a 5-day incubation period at $25^{\circ} \mathrm{C}$. Plugs of mycelial mat from $\mathrm{Si}$-amended plates were transferred to PDA plates without $\mathrm{Si}$ to 
determine whether the effect of $\mathrm{Si}$ was fungistatic or fungicidal. Plates were incubated for 5 days at $25^{\circ} \mathrm{C}$ and colony diameter was measured. Each treatment contained three replicates of six plates each and the experiment was performed twice.

In vivo assays. Artificial inoculation. The effect of $\mathrm{Si}$ on inoculated fruit was assayed using the method of $\mathrm{Bi}$ and Zhang (6). Fruit were dipped for $10 \mathrm{~min}$ in the various concentrations $(25,50,100$, and $200 \mathrm{mM}$ ) of Si and air dried. Control fruit were dipped in distilled water. Treated melons of New Queen and 8601 were sampled from ambient temperature storage (at $22 \pm 2^{\circ} \mathrm{C}$ ) 1 day after Si treatment. Nine spots (approximately $1 \mathrm{~cm}$ in diameter) were disinfected with a ball of absorbent cotton containing $70 \%$ ethanol around the equator of each melon. Wounds were made on the disinfected spots with a sterile needle (3 $\mathrm{mm}$ deep by $3 \mathrm{~mm}$ in diameter). Spore suspensions $\left(20 \mu \mathrm{l}, 1 \times 10^{5}\right.$ spores $\mathrm{ml}^{-1}$ ) of each of three pathogens (A. alternata, $F$. semitectum, or $T$. roseum) were pipetted into each of nine wounds. After drying for approximately $1 \mathrm{~h}$ in air, the melons were put in boxes, covered with plastic film to increase RH to 85 to $90 \%$, and kept at $22 \pm 2{ }^{\circ} \mathrm{C}$. Decay incidence and decay severity were determined 14 (for $A$. alternata), 11 (for $F$. semitectum), and 9 (for $T$. roseum) days after inoculation. Each treatment was applied to three replicates of 12 melons and the experiment was performed three times.

Natural infection. Fruit of cvs. New Queen and 8601, treated with distilled water (control), 50, and $100 \mathrm{mM}$ of $\mathrm{Si}$, were stored for 14 days respectively at 22 $\pm 2^{\circ} \mathrm{C}$ with $\mathrm{RH}$ of 85 to $90 \%$ (the time period and environment conditions correspond to those occurring during land freight delivery from northwestern to southern China and retail marketing). Fruit quality was evaluated after storage. General appearance was evaluated visually as described by Aharoni et al. (2), for freshness of the fruit, decay, and skin blemishes on a scale of 1 to 5 , where $1=$ poor, $3=$ good, and $5=$ excellent quality. Fruit with a rating of less than 2.5 were considered unfit for marketing. Total soluble solids (TSS) were determined by squeezing juice from the central section of flesh directly onto an Abbe refractometer (10481 S/N; Division of Warner-L Ambert Technologies, Inc., Keene, NH). Three readings were taken from each melon. Firmness was measured using a handheld penetrometer (FT-327; UC Fruit Firmness Tester, Milano, Italy), equipped with an 8-mm plunger tip, at the equator of fruit where a section of rind ( 4 by $4 \mathrm{~cm}$ and $1 \mathrm{~cm}$ deep) had been removed. Three readings were taken for each melon. Fruit were considered to be decayed if there was fungal growth on the surface of the stem end and the rind. Fungi associated with rots were isolated and plated onto PDA. The isolates were identified and tested for pathogenicity by wounding and applying a spore suspension as described above. Percentage of fruit with decay was determined. Each treatment was applied to three replicates of 20 melons and the experiment was performed twice.

Pre- and post-inoculation effect of $\mathrm{Si}$ treatment. The possibilities of fruit fungistatic effect and induced resistance as mechanisms of action of Si were examined with melons which were inoculated 6 and $24 \mathrm{~h}$ before or 6 and $24 \mathrm{~h}$ after Si treatment at $100 \mathrm{mM}$. The melons (cvs. New Queen and 8601) were disinfected and inoculated with a suspension of $T$. roseum $\left(1 \times 10^{5}\right.$ spores $\mathrm{ml}^{-1}$ ) as described above. Fruit were stored and evaluated for decay incidence and severity 9 days after inoculation as described above. Each treatment was applied to three replicate units made up of 12 melons. The experiment was done twice.

Enzyme assays. Fruit treated with $\mathrm{Si}$ $(100 \mathrm{mM})$ or water (control) were inoculated with $T$. roseum $\left(1 \times 10^{5}\right.$ spores $\left.\mathrm{ml}^{-1}\right)$ $24 \mathrm{~h}$ after treatment. Approximately $2 \mathrm{~g}$ of tissue were removed 0.5 to $1.5 \mathrm{~cm}$ below the skin and $1 \mathrm{~cm}$ from the edge of the wound with a stainless steel cork borer 0 , $1,3,5,7$, and 9 days after inoculation for New Queen and 0, 2, 4, 6, 8, and 10 days after inoculation for 8601 . Each sample was packed, frozen in liquid nitrogen, and kept at $-80^{\circ} \mathrm{C}$ until crude enzyme extraction.

Crude enzyme was extracted according to the method of Venisse et al. (35) with some modifications. Frozen tissue (2 g) was homogenized with a mortar and pestle in $2 \mathrm{ml}$ of cold sodium phosphate buffer (50 mM, pH 7.5) containing $1 \mathrm{mM}$ polyethyleneglycol, $1 \mathrm{mM}$ phenylmethylsulfonyl fluoride, $8 \%$ (wt/vol) polyvinypolypyrolidone, and $0.01 \%$ Triton X-100. Homogenates were centrifuged at 16,000 $\times$ $g$ for $20 \mathrm{~min}$ at $4^{\circ} \mathrm{C}$, and supernatants were assayed immediately for enzyme activities.

Peroxidase (POD) activity was determined according to the methods of Chance and Maehly (11) with some modifications. Supernatants were diluted in $50 \mathrm{mM}$ sodium phosphate buffer, $\mathrm{pH} 7.5$ ( $\mathrm{vol} / \mathrm{vol}$, 1:4 for 8601 or $1: 3$ for New Queen). This diluted extract $(50 \mu \mathrm{l})$ was added to a $1-\mathrm{ml}$ reaction mixture that contained $50 \mathrm{mM}$ sodium acetate buffer, $\mathrm{pH} 5.5,25 \mathrm{mM}$ guaiacol, and $250 \mathrm{mM} \mathrm{H}_{2} \mathrm{O}_{2}$. Oxidation of guaiacol to tetraguaiacol was monitored spectrophotometrically at $470 \mathrm{~nm}$ for 1 min at $30^{\circ} \mathrm{C}$. POD activity was expressed as $\mathrm{nM}$ tetraguaiacol produced per minute and per milligram of proteins using a molar extinction coefficient of $26.6 \mathrm{mM} / \mathrm{cm}$.

Chitinase (CHT) activity was assayed according to the method of Wirth and Wolf (36) with some modifications. Carboxymethyl-curdlan-Remazol Brilliant Violet (CM-curdlan-RBV) was used as the respective substrate (Loewe Biochemica, Otterfing, Gremany). CM-curdlan-RBV
$(100 \mu \mathrm{l})$ at $200 \mu \mathrm{g} / \mathrm{ml}$ was prepared in sodium acetate buffer (200 mM, pH 5), preincubated at $35^{\circ} \mathrm{C}$ for $10 \mathrm{~min}$, and then mixed with $200 \mu \mathrm{l}$ of crude supernatant. The mixture was incubated at $35^{\circ} \mathrm{C}$ for 30 min and the reaction immediately stopped by addition of $2 \mathrm{~N} \mathrm{HCl}(100 \mu \mathrm{l})$. For a reference, the reaction was stopped immediately with $\mathrm{HCl}$ after the addition of the substrate. Nondigested substrate was precipitated after $10 \mathrm{~min}$ of incubation on ice, then separated from the digested substrate by centrifugation at $10,000 \times g$ for $10 \mathrm{~min}$. CHT activity was calculated from the difference of absorbance at $550 \mathrm{~nm}$ between the incubated sample and the reference. Data were expressed as the increase of absorbance per minute and per milligram of protein.

Protein content in the crude enzyme extracts was determined according to the method of Bradford (9) using bovine serum albumin (BSA) as the standard protein.

The enzyme tests were performed with a minimum of three tissue sample replicates per treatment and per time point. Each experiment was repeated at least three times.

Statistical analysis. Data analyses were performed with SPSS software (SPSS Inc., Chicago). Analysis of variance was conducted on decay severity and arcsinesquare root transformed data from decay incidence in various trials. Data from separate experiments were combined when statistical analyses determined that variances were homogeneous. Significant differences $(P<0.05)$ between treatments were determined with the least significant difference. Data analysis indicated that treatment effects were similar among the experimental repeats. Results presented were pooled across repeated experiments.

\section{RESULTS}

Effect of Si concentration on mycelial growth of the three pathogens in vitro. The mycelial growth of the three pathogens on PDA significantly decreased with increasing $\mathrm{Si}$ concentration (Fig. 1). A concentration of $\mathrm{Si}$ at $100 \mathrm{mM}$ completely inhibited the mycelial growth of all pathogens. $T$. roseum was more sensitive to $\mathrm{Si}$ than A. alternata and $F$. semitectum. After 5 days at $25^{\circ} \mathrm{C}$, the mycelial growth of $T$. roseum was reduced by $72 \%$ at $25 \mathrm{mM}$ of Si (Fig. 1C) compared with the mycelial growth of $A$. alternata and $F$. semitectum which was reduced by 62 and $40 \%$, respectively (Fig. 1A and B). There was no difference in growth rates when compared with plugs of unamended controls after transfer from $\mathrm{Si}$-amended to PDA without $\mathrm{Si}$ (data not shown). This indicated that $\mathrm{Si}$ lacked fungicidal effect.

Effect of Si treatment on decay incidence and severity of inoculated melons. Treatment with $\mathrm{Si}$ reduced significantly decay incidence and severity of the three 
pathogens on inoculated melons (Fig. 2). A concentration of $\mathrm{Si}$ at $100 \mathrm{mM}$ provided the most decay control; decay incidence was reduced by 72,40 , and $59 \%$ in New Queen and 67, 42, and 48\% in 8601 after inoculation with $T$. roseum, $F$. semitectum, and A. alternata, respectively (Fig. $2 \mathrm{~A}$ and B). The Si treatment at $100 \mathrm{mM}$ had the smallest decay severity, which was decreased by 47, 23, and 35\% in New Queen and 46,19 , and $26 \%$ in 8601 after inoculation with $T$. roseum, $F$. semitectum, and $A$. alternata, respectively (Fig. 2C and D). Among the three pathogens, Si treatment was most effective against $T$. roseum. A concentration of $200 \mathrm{mM}$ did not inhibit the disease further and resulted in rind injury, which consisted of sunken areas 1 to $3 \mathrm{~mm}$ in depth that were light to dark brown in color.

Effect of Si treatments on natural infections and quality of melons. Si treatments were effective in reducing incidence of decay in New Queen and 8601 melons after 14 days at $22 \pm 2^{\circ} \mathrm{C}$. The treated fruit had a high score for general appearance and were marketable (Table 1). Si treatment at $100 \mathrm{mM}$ provided effective control
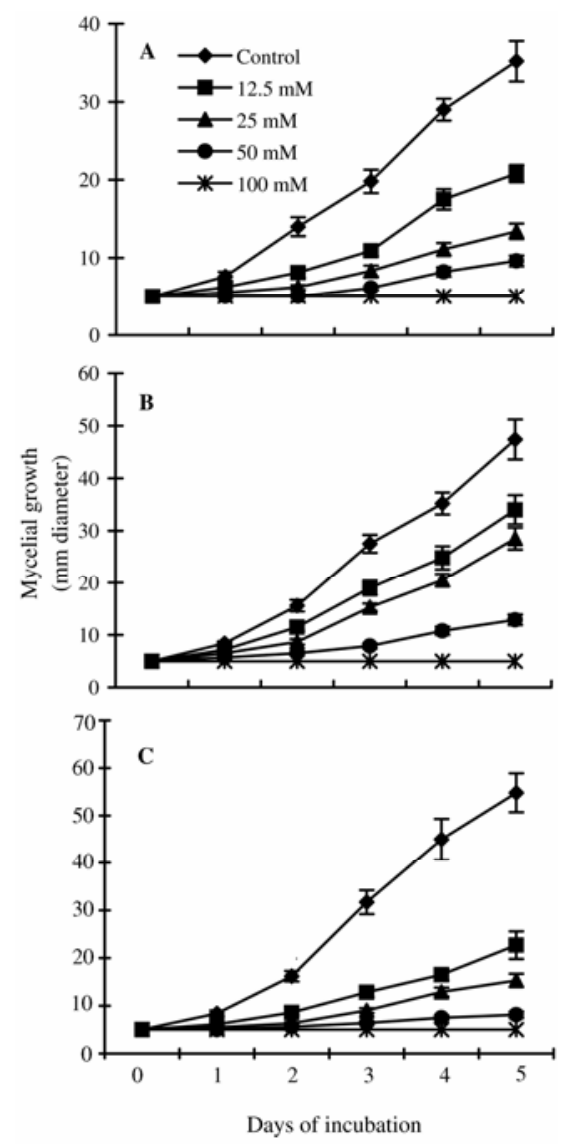

Fig. 1. Effect of sodium silicate on mycelial growth of A, Alternaria alternata, B, Fusarium semitectum, and $\mathbf{C}$, Trichothecium roseum in vitro during 5 days of incubation at $25^{\circ} \mathrm{C}$. Data were based on three replicates of six plates and the experiment was performed twice. Vertical bars represent the standard error from the means of three separate tests. of decay, with $61 \%$ fewer decayed melons for New Queen and 70\% fewer for 8601 compared with nontreated melons. Infection occurred more commonly at the stem end and in cracks and nets on the rind. Approximately $70 \%$ of rot was identified as caused by Fusarium spp. Other pathogens were A. alternata, Mucor mucedo, Rhizopus stolonifer, and $T$. roseum. The fruit firmness and TSS on New Queen and 8601 melons did not differ between treatments (Table 1).

Pre- and post-inoculation effect of $\mathrm{Si}$ treatment. Both New Queen and 8601 melons treated with $100 \mathrm{mM}$ of $\mathrm{Si}$ from 24 $\mathrm{h}$ before to $6 \mathrm{~h}$ after inoculation with $T$. roseum had lower decay incidence and

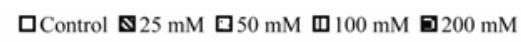

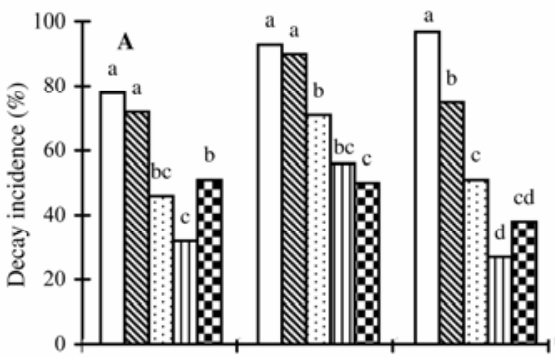

口Control $\mathbf{\otimes} 25 \mathrm{mM}$ 口50 mM $\mathbf{\square} 100 \mathrm{mM} \boldsymbol{\square} 200 \mathrm{mM}$
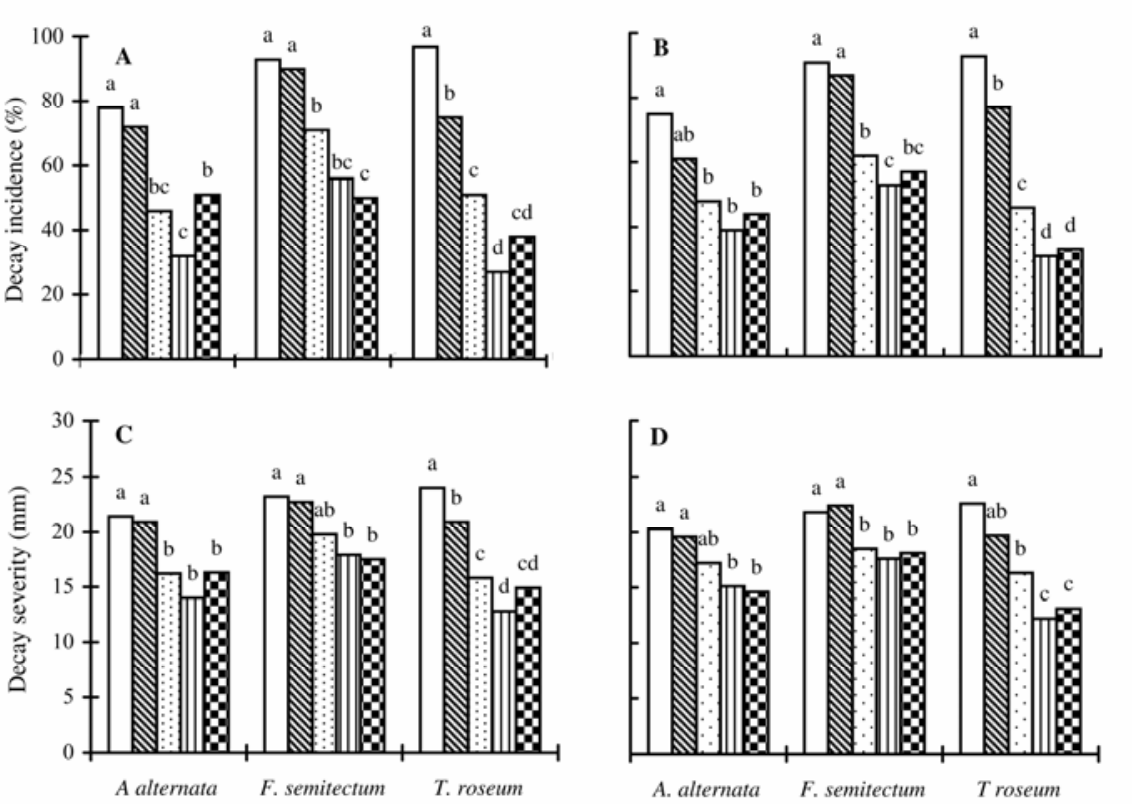

Fig. 2. Effect of sodium silicate ( $\mathrm{Si}$ ) treatment on $\mathbf{A}$ and $\mathbf{B}$, decay incidence and $\mathbf{C}$ and $\mathbf{D}$, decay severity in Hami melon cvs. A and C, New Queen and B and D, 8601. Fruit were treated with Si at 25, 50,100 , and $200 \mathrm{mM}$ or water (control) for $10 \mathrm{~min}$ and inoculated with $20 \mu \mathrm{l}$ of spore suspensions $(1 \times$ $10^{5}$ spores $\mathrm{ml}^{-1}$ ) of Alternaria alternata, Fusarium semitectum, and Trichothecium roseum 1 day after treatment. Decay was evaluated 14 (for A. alternata), 11 (for F. semitectum), and 9 (for T. roseum) days after incubation at $22 \pm 2{ }^{\circ} \mathrm{C}$. Data are averages of three replicates each of 12 fruit for one of three experiments that produced similar results. Bars with the same letters represent values that are not significantly different according to the least significance difference test $(P<0.05)$.

Table 1. Decay incidence and quality of Hami melons 14 days after treatment with sodium silicate $(\mathrm{Si})^{\mathrm{y}}$

\begin{tabular}{lcccc}
\hline Cultivars, treatment & $\begin{array}{c}\text { Decay incidence } \\
(\boldsymbol{\%})\end{array}$ & $\begin{array}{c}\text { General } \\
\text { appearance }^{\mathbf{z}}\end{array}$ & $\begin{array}{c}\text { Firmness } \\
(\mathbf{N})\end{array}$ & $\begin{array}{c}\text { Total soluble } \\
\text { solids }(\%)\end{array}$ \\
\hline New Queen & & & & \\
Before storage & 0 & 4.5 & 55 & 11.7 \\
Control & $27 \mathrm{a}$ & $2.0 \mathrm{c}$ & $37 \mathrm{a}$ & $10.5 \mathrm{a}$ \\
Si at $50 \mathrm{mM}$ & $19 \mathrm{~b}$ & $3.0 \mathrm{~b}$ & $35 \mathrm{a}$ & $10.8 \mathrm{a}$ \\
Si at $100 \mathrm{mM}$ & $11 \mathrm{c}$ & $3.5 \mathrm{a}$ & $39 \mathrm{a}$ & $10.2 \mathrm{a}$ \\
8601 & & & & 12.4 \\
Before storage & 0 & 4.5 & 62 & $11.0 \mathrm{a}$ \\
Control & $16 \mathrm{a}$ & $3.0 \mathrm{c}$ & $56 \mathrm{a}$ & $10.6 \mathrm{a}$ \\
Si at $50 \mathrm{mM}$ & $9 \mathrm{~b}$ & $3.5 \mathrm{~b}$ & 54 & $11.3 \mathrm{a}$ \\
Si at $100 \mathrm{mM}$ & $5 \mathrm{~b}$ & $4.0 \mathrm{~b}$ & $53 \mathrm{a}$ & \\
\hline
\end{tabular}

y Data were based on three replicates of 20 fruit each. The experiment was performed twice with similar results and the treatment means were pooled. Values followed by the same letter are not significantly different according to the least significant difference test $(P<0.05)$.

${ }^{\mathrm{z}}$ General appearance: $1=$ poor, $3=$ good, and $5=$ excellent.

decay severity than control fruit. $\mathrm{Si}$ was
less effective when fruit were inoculated and smallest decay severity occurred with ith Si (Fig. 3).

CHT activities in melons challenged by T. roseum. Si treatment at $100 \mathrm{mM}$ caused in POD and CHT activities on fruit challenged by $T$. roseum (Fig. 4). The maximum POD activity was found 3 days after
inoculation in New Queen and 6 days after in 8601 , with the activity over 2.4 and 2 times higher in the fruit treated with $\mathrm{Si}$ than in the control, respectively (Fig. 4A 
and B). CHT activity reached maximum 5 days after inoculation in New Queen and 6 days after in 8601, which was over 2.2 and 1.6 higher than nontreated fruit in New
Queen and 8601, respectively (Fig.4C and D). The activation of POD and CHT lasted at least 9 days in New Queen and 10 days in 8601 .

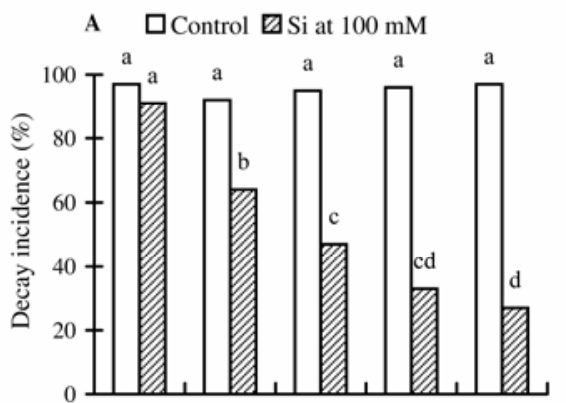

B $\square$ Control $\mathbb{S i}$ at $100 \mathrm{mM}$
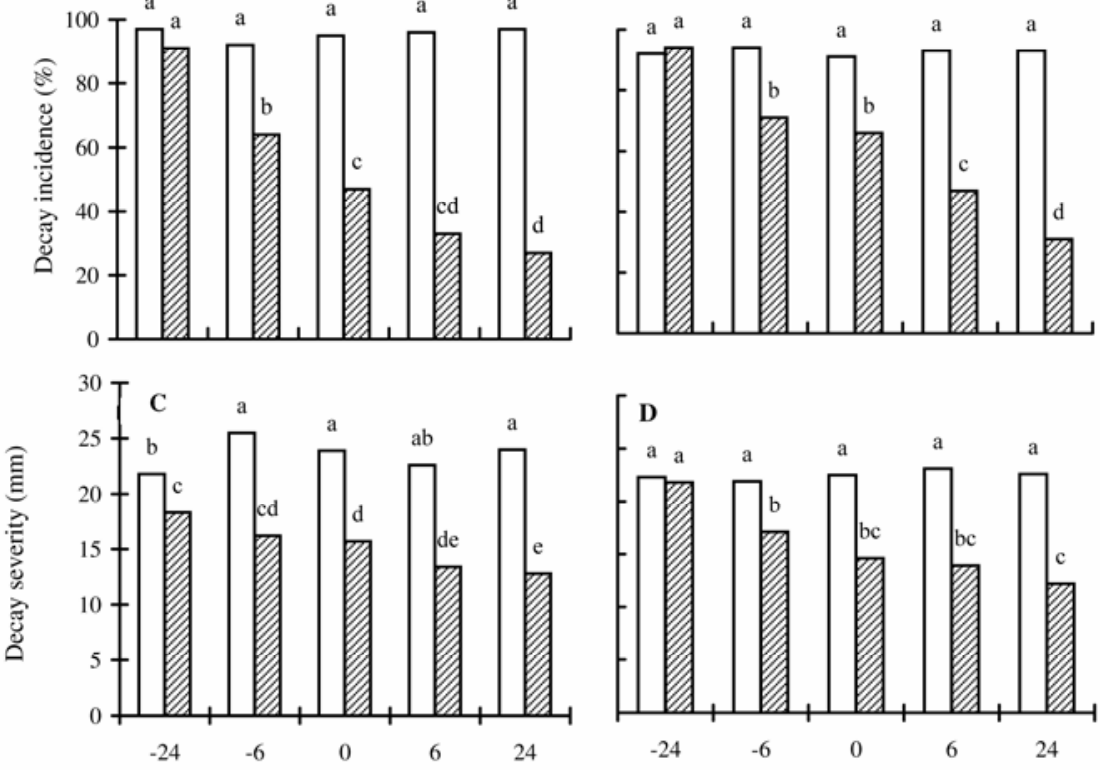

Hours inoculation before/after Si treatment

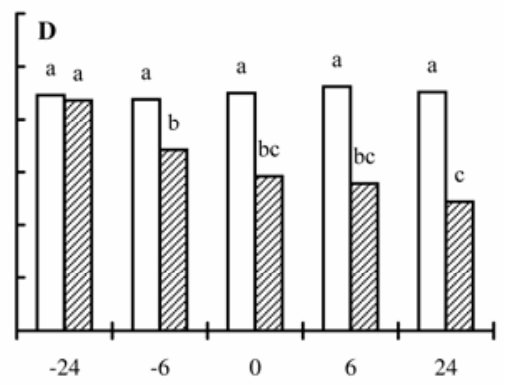

Hours inoculation before / after Si treatment

Fig. 3. Pre- and post-inoculation effect of sodium silicate ( $\mathrm{Si}$ ) on $\mathbf{A}$ and $\mathbf{B}$, decay incidence and $\mathbf{C}$ and $\mathbf{D}$, decay severity in Hami melon cvs. A and $\mathbf{C}$, New Queen and $\mathbf{B}$ and $\mathbf{D}, 8601$. Fruit were treated with Si at $100 \mathrm{mM}$ or water (control) for $10 \mathrm{~min}$ and inoculated with $20 \mu \mathrm{l}$ of spore suspensions $\left(1 \times 10^{5}\right.$ spores ml-1) of Trichothecium roseum either 6 and $24 \mathrm{~h}$ before $(-24$ and -6$)$ or 6 and $24 \mathrm{~h}$ after $(6$ and 24) treatment. Decay was evaluated 9 days after incubation at $22 \pm 2^{\circ} \mathrm{C}$. Data are averages of three replicates each of 12 fruit for one of three experiments that produced similar results. Bars with the same letters represent values that are not significantly different according to the least significance difference test $(P<0.05)$.
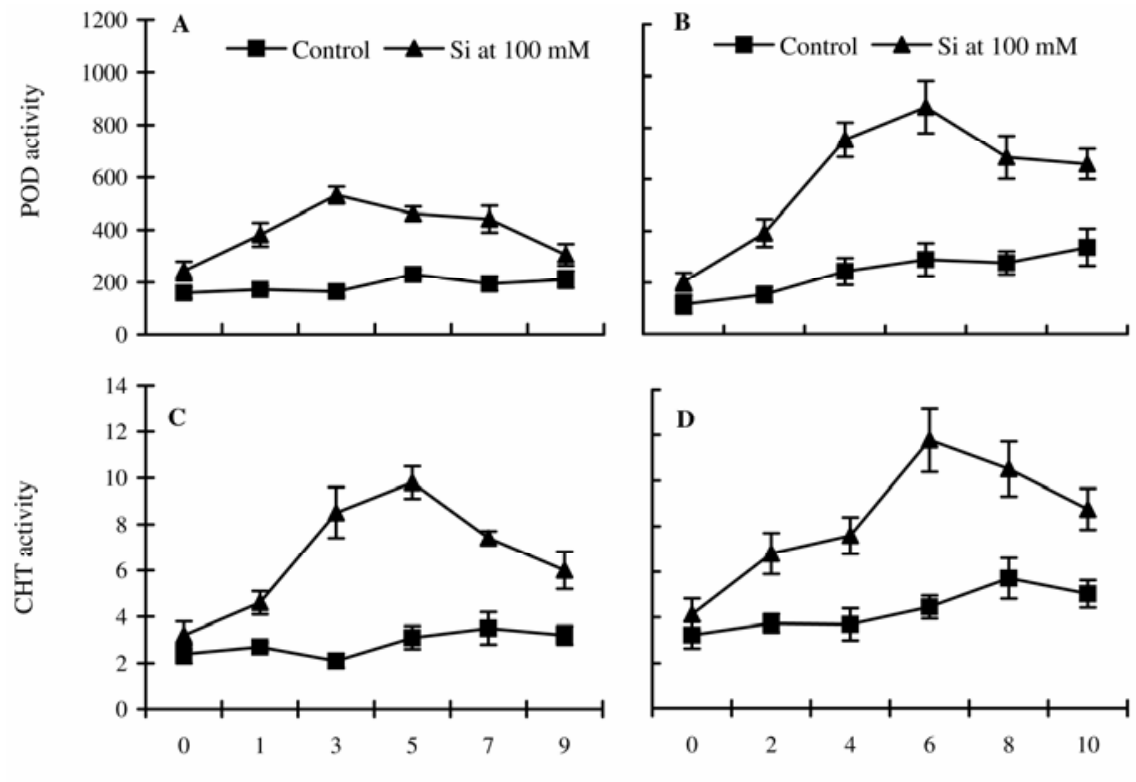

Days after inoculation

Days after inoculation

Fig. 4. Change of $\mathbf{A}$ and $\mathbf{B}$, peroxidase (POD) and $\mathbf{C}$ and $\mathbf{D}$, chitinase (CHT) activities in Hami melon cvs. $\mathbf{A}$ and $\mathbf{C}$, New Queen and $\mathbf{B}$ and $\mathbf{D}, 8601$ treated with sodium silicate $(\mathrm{Si})$ at $100 \mathrm{mM}$ or water (control) and challenged with $20 \mu \mathrm{l}$ of spore suspensions $\left(1 \times 10^{5}\right.$ spores $\left.\mathrm{ml}^{-1}\right)$ of Trichothecium roseum $24 \mathrm{~h}$ later during storage at $22 \pm 2^{\circ} \mathrm{C}$. Enzyme activities are expressed in $\mathrm{nM}$ tetraguaiacol produced per minute per milligram of proteins (POD) and in increase of absorbance at $550 \mathrm{~nm}$ per minute per milligram of proteins (CHT). Each treatment contained three replicates, and the test was performed three times. Vertical bars represent the standard error from the means of three separate tests.

\section{DISCUSSION}

Postharvest treatment with Si proved effective for inhibiting pathogen growth as well as inducing disease resistance in Hami melons, thereby controlling decay and maintaining fruit quality. This is, to our knowledge, the first report linking the beneficial role of $\mathrm{Si}$ against decay with an induced defense mechanism in melon. Si at $100 \mathrm{mM}$ was the most effective concentration in reducing decay, whereas a higher Si concentration (200 mM) was phytotoxic, which led to an unacceptable general appearance.

In our study, Si directly inhibited mycelial growth of A. alternata, F. semitectum, and T. roseum in vitro (Fig. 1). A concentration of Si at $100 \mathrm{mM}$ completely inhibited the mycelial growth of the three pathogens. Similar results also were observed with Penicillium expansum and Monilinia fructicola $(8,27)$. Because the three pathogens grew normally after transfer from Si-amended PDA to PDA without $\mathrm{Si}$, the action of $\mathrm{Si}$ was fungistatic rather than fungicidal against these pathogens. A study currently underway has shown that Si caused reduction in cell turgor pressure of A. alternata, $F$. semitectum, and $T$. roseum, which resulted in collapse and shrinkage of hyphae and spores and consequent inability of fungi to sporulate in vitro (Y. $\mathrm{Bi}$, data not shown). We suspect that these changes are related to the fungistatic effects of $\mathrm{Si}$ on the three pathogens of Hami melons.

Although the effects of soluble $\mathrm{Si}$ on diseases of crops have been reported for many years, little is known about its mode of action. Several attempts have been made to determine the possible mechanisms by which this element enhances disease resistance and interferes with fungal development. Stimulating natural defenses seemed to be the main mechanism (4). In this study, we found that disease development was significantly reduced on melons inoculated with the three pathogens 1 day after Si treatment (Fig. 2). Si treatment at $100 \mathrm{mM}$ concentration before inoculation with $T$. roseum resulted in lower decay incidence and severity than treatment after inoculation (Fig. 3). This suppression clearly was correlated with induction of POD and CHT in treated fruit (Fig. 4). Si appears to induce or enhance resistance in the host.

The role of POD and CHT in defense mechanisms for host-pathogen interaction has been demonstrated previously in a number of plants (15). POD contributes to cell-wall reinforcement and is involved in the final steps of lignin biosynthesis and in the cross-linking of cell-wall protein $(10,21)$. The enzyme often is used as a biochemical marker to predict disease resistance $(7,28)$. In Hami melons, the present results showed a significant accumulation of POD in fruit treated with $\mathrm{Si}$ and challenged with $T$. roseum $24 \mathrm{~h}$ later 
(Fig. 4), which could increase the resistance against the pathogen by accelerating the rigidification of the cell wall. Fungal establishment and spread in intercellular spaces of parenchyma cells, and cell wall fortification, could limit their progression. CHT is one of the pathogenesis-related (PR) proteins in many plants (31). The enzyme hydrolyzes the cell wall of many phytopathogenic fungi $(23,26,34)$. In this study, an increase of CHT activity also was observed in melons treated with $\mathrm{Si}$, then challenged by $T$. roseum. Similar results were obtained by Chérif et al.(12), who demonstrated that several enzymes, including POD and CHT, had increased activity in cucumber plants treated with soluble silicon and challenged by Pythium ultimum. The present results support the hypothesis that $\mathrm{Si}$ is able to induce plant defense mechanisms that are expressed in response to fungal infection. These responses are multicomponent and appear to be contingent on the activation of a cascade of associated biochemical changes leading to rapid and extensive defense reactions. The multicomponent nature of these responses may explain the nonspecificity of Si-induced resistance to a wide spectrum of unrelated pathogens $(3,13,25)$. Si present in the plant cells may mediate some defense responses that are functionally similar to systemic acquired resistance (20). However, we cannot exclude induction of other defense mechanisms which may be attributed to $\mathrm{Si}$-induced resistance in melons and other systems such as accumulation of flavonoid and diterpenoid phytoalexins in cucumber and rice, respectively $(19,30)$.

The primary findings of this work are that $\mathrm{Si}$ has broad-spectrum antimicrobial properties and. may enhance fruit natural defenses. Considering that $\mathrm{Si}$ is the second most abundant atom in the Earth's crust, it is inexpensive and readily available. The cost of the Si treatment is cheaper than other new strategies. It has great commercial potential as a decay-control product. Further research is needed to test $\mathrm{Si}$ on additional melons types and on other host plants to confirm its broad-spectrum property and identify optimal doses.

\section{ACKNOWLEDGMENTS}

This research was supported by the grants from the Ministry of Science and Technology of China (2001BA501A09) and the Australian Center for International Agricultural Research (ACIAR, PHT/1998/140). We thank K. McDonald (Faculty of Agriculture, Food and Natural Resources, Sydney University) for critically reading the manuscript and J. Zijun (Jiuquan Fruit Ltd. Co.) and O. Chunguang (Analysis Center, Gansu Academy of Sciences) for their help with the experiment.

\section{LITERATURE CITED}

1. Aharoni, Y., Copel, A., Davidson, H., and Baikai-Golan, R. 1992. Fungicide application in water and in wax for decay control in ' $\mathrm{Ga}$ - lia' melons. N. Z. J. Crop Hortic. Sci. 20:177179.

2. Aharoni, Y., Fallik, F., Copel, A., Gil, M., Grinberg, S., and Klein, J. D. 1997. Sodium bicarbonate reduces postharvest decay development on melons. Postharvest Biol. Technol. 10:201-206.

3. Aleshin, N. E., Avakyan, E. R., Dyakun Chak, S. A., Aleshin, E. P., Baryshok, V. P., and Vorokov, M. G. 1986. Role of silicon in resistance of rice to blast. Dokl. Akad. Nauk SSSR 291:499-502.

4. Bélanger, R. R., Bowen, P. A., Ehret, D. L., and Menzies, J. G. 1995. Soluble silicon: Its role in crop and disease management of greenhouse crops. Plant Dis. 79:329-336.

5. Bi, Y., Tian, S. P., Liu, H. X., Zhao, J., Cao, J. K., Li, Y. C., and Zhang, W. Y. 2003. Effect of temperature on chilling injury, decay and quality of Hami melon during storage. Postharvest Biol. Technol. 29:229-232.

6. Bi, Y., and Zhang, W. Y. 1991. Control of postharvest disease in Hami melon by treating inoculated fruits with fungicide and hot water. Acta Phytophylacica Sin. 18:362-363.

7. Bi, Y., and Zhang, W. Y. 1993. On changes of respiratory rate, ethylene evolution and peroxidase activity of the infected melon. Acta Phytopathol. Sin. 23:69-73.

8. Biggs, A. R., El-Kholi, M. M., El-Neshawy, S., and Nickerson, R. 1997. Effects of calcium salts on growth, polygalacturonase activity, and infection of peach fruit by Monilinia fructicola. Plant Dis. 81:399-403.

9. Bradford, M. M. 1976. A rapid and sensitive method for quantitation of microgram quantities of protein utilizing the principle of proteindye binding. Anal. Biochem. 72:248-254.

10. Brisson, L. F., Tenhaken, R., and Lamb, C. J. 1994. Function of oxidative cross-linking of cell wall structural proteins in plant disease resistance. Plant Cell 6:1703-1712.

11. Chance, B., and Maehly, A.C. 1955. Assay of catalases and peroxidases. Method Enzymol. 2:764-775.

12. Chérif, M., Asselin, A., and Bélanger, R. R. 1994. Defense responses induced by soluble silicon in cucumber roots infected by Pythium spp. Phytopathology 84:236-242.

13. Chérif, M., and Bélanger, R. R. 1992. Use of potassium silicate amendments in recirculating nutrient solution to suppress Pythium ultimum on long English cucumber. Plant Dis. 76:10081011 .

14. Chérif, M., Benhamou, N., Menzies, J. G., and Bélanger, R. R. 1992. Silicon-induced resistance in cucumber plants against Pythium ultimum. Physiol. Mol. Plant Pathol. 41:411-425.

15. Conrath, U., Pieterse, C. M. J., and MauchMani, B. 2002. Priming in plant-pathogen interactions. Trends Plant Sci. 7:210-216.

16. El Ghaouth, A. 1994. Manipulation of defense systems with elicitors to control postharvest disease. Pages 153-167 in: Biological Control of Postharvest Diseases: Theory and Practice. C. L. Wilson and M. E. Wisniewski, eds. CRC Press, Boca Roton, FL.

17. Epstein, E. 1994. The anomaly of silicon in plant biology. Proc. Natl. Acad. Sci. USA 91:11-17.

18. Epstein, E. 1999. Silicon. Annu. Rev. Plant Physiol. Plant Mol. Biol. 50:641-664.

19. Fawe, A., Abou-Zaid, M., Menzies, J. G., and Bélanger, R. R. 1998. Silicon-mediated accumulation of flavonoid phytoalexins in cucumber. Phytopathology 88:396-401.

20. Fawe, A., Menzies, J. G., Chérif, M., and Bélanger, R. R. 2001. Silicon and disease resistance in dicotyledons. Pages 159-169 in: Silicon in Agriculture. L. E. Datnoff, G. H.
Snyder, and G. H. Korndorfer, eds. Elsevier Science, New York.

21. Kombrink, E., and Somssich, I. E. 1995. Defense responses of plants to pathogens. Adv. Bot. Res. 21:1-34

22. Ma, L. Y., Bi, Y., Zhang, Z. K., Zhao, L., An, L., and Ma, K. Q. 2004. Control of pre- and postharvest main diseases on melon variety Yindi with preharvest azoxystrobin spraying. J. Gansu Agric. Univ. 39:14-17.

23. Mauch, F., Hadwiger, L. A., and Boller, T. 1988. Antifungal hydrolases in pea tissue. II. Inhibition of fungal growth by combination of chitinase and $\beta$-1,3-glucanase. Plant Physiol. 88:936-942.

24. Menzies, J. G., Bowen, P. A., and Ehret, D. L. 1992. Foliar application of potassium silicate reduce severity of powdery mildew on cucumber, muskmelon and zucchini squash. J. Am. Soc. Hortic. Sci. 117:902-905.

25. Menzies, J. G., Bowen, P. A., Ehret, D. L., Glass, A. D. M., Helmer, T., Koch, C., and Seywerd, F. 1991. Effects of soluble silicon on the parasitic fitness of Sphaerotheca fuliginea on Cucumis sativus. Phytopathology 81:84-88.

26. Pan, S. Q., Ye, X. S., and Kuc, J. 1992. Induction of chitinases in tobacco plants systemically protected against blue mold by Peronospora tabacina or tobacco mosaic virus. Phytopathology 82:119-123.

27. Qin, G. Z., and Tian, S. P. 2005. Enhancement of biocontrol activity of Cryptococcus laurentii by silicon and the possible mechanisms involved. Phytopathology 95:69-75.

28. Reuveni, R., Shimoni., Karchi, Z., and Kuc, J. 1992. Peroxidase activity as a biochemical marker for resistance of muskmelon (Cucumis melo) to Pseudoperonospora cubensis. Phytopathology 82:749-753.

29. Rochow, E. G. 1973. The element. Pages 1323-1348 in: The Chemistry of Silicon. J. C. Bailar, H. J. Emeleus, R. Nyholm, and A. F. Trotman-Dickenson, eds. Pergamon Press, Oxford.

30. Rodrigues, F. A., McNally, D. J., Datnoff, L. E., Jones, J. B., Labbé, C., Benhamou, N., Menzies, J. G., and Bélanger, R. R. 2004. Silicon enhances the accumulation of diterpenoid phytoalexins in rice: a potential mechanism for blast resistance. Phytopathology 94:177-183.

31. Shewry, P. R., and Lucas, J. A. 1997. Plant proteins that confer resistance to pests and pathogens. Adv. Bot. Res. 26:135-192.

32. Spotts, R. A., and Cervantes, L. A. 1989. Evaluation of disinfestant-flotation saltsurfactant combinations on decay fungi of pear in a model dump tank. Phytopathology 79:121126.

33. Sugar, D., and Spotts, R. A. 1986. Effect of flotation salt solutions on spore germination of four decay fungi and on side rot of pear. Plant Dis. 70:1110-1112.

34. VanLoon, L. C. 1997. Induced resistance in plants and the role of pathogenesis-related proteins. Eur. J. Plant Pathol. 103:753-765.

35. Venisse, J. S., Gullner, G., and Brisset, M. N. 2001. Evidence for the involvement of an oxidative stress in the initiation of infection of pear by Erwinia amylovora. Plant Physiol. 125:2164-2172.

36. Wirth, S. J., and Wolf, G. A. 1992. Microplate colourimetric assay for endo-acting cellulase, xylanase, chitinase, 1,3- $\beta$-glucanase and amylase extrated from forest soil horizons. Soil Biol. Biochem. 24:511-519.

37. Werner, D., and Roth, R. 1983. Silica metabolism. Pages 682-694 in: Encyclopedia of Plant Physiology, New Series. Vol. 15B. A. Lächl and R. L. Bicleski, eds. Springer-Verlag, New York. 